\title{
Evaluation of peritoneal adhesions formation and tissue response to polypropylene - poli (2-hydroxyethyl methacrylate)-(polyHEMA) implant on rats' abdominal wall ${ }^{1}$
}

\author{
Avaliação da formação de aderências peritoneais e da resposta tecidual ao implante de poli \\ (2-hidroxietil dimetacrilato)-(poliHEMA) na parede abdominal de ratos
}

\author{
Neusa Margarida PauloI, Sonia Maria Malmonge ${ }^{\mathrm{II}}$, Liliana Borges de Menezes ${ }^{\mathrm{III}}$, Flávia Gontijo de Lima ${ }^{\mathrm{IV}}$, Aline de Moraes \\ Fariav $^{\text {, }}$ Mariana Moreira Andrasckhov , Natalia Menezes Moreirav ${ }^{\text {, Ingrid Bueno Atayde }}{ }^{\mathrm{VI}}$, Marcelo Seixo de Brito e Silva ${ }^{\mathrm{VII}}$ \\ I Associate Professor, Veterinary Surgery, Department of Veterinary Medicin, UFG, Goiânia-GO, Brazil. \\ ${ }^{\text {II }} \mathrm{PhD}$, Associate Professor, Center of Engineering, Modeling and Socials Applies Sciences, Federal University of ABC, Santo André-SP, Brazil. \\ III PhD, Associate Professor, Department of Microbiology, Immunology, Parasitology and Pathology, IPTSP, UFG, Goiânia-GO, Brazil. \\ ${ }^{\text {IV }}$ Fellow PhD degree, Postgraduate Program in Animal Science, School of Veterinary, UFG, Goiânia-GO, Brazil. \\ ${ }^{v}$ Graduate student, School of Veterinary Medicine, UFG, Goiânia-GO, Brazil. \\ ${ }^{\text {VI }} \mathrm{PhD}$, Head Professor, Animal Physiology, UNIP, Goiânia-GO, Brazil.

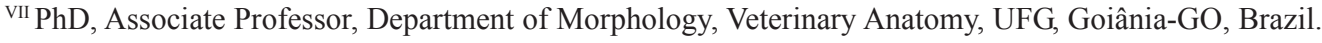

\begin{abstract}
Purpose: To verify if the composit poli (2-hydroxyethyl methacrylate)-PolyHEMA/polypropylene mesh implanted in the female rat's abdominal wall could be suitable for the prevention of peritoneal adhesions, and for the evaluation of the tecidual response produced by this biomaterial. Methods: Polypropylene meshes (Group PP, n=20) and polypropylene meshes coated with a layer of poli (2-hydroxyethyl methacrylate)-PolyHEMA (Group PH, n=20) were implanted on the abdominal wall of Wistar female rats. Ten animals from each group were submitted to euthanasia at 15 and 30 days of the postoperative period. Results: The animals from the group PP presented visceral adhesions on the mesh surface, which was not observed in the ones from group PH. At the histopathological examination foreign body response was observed in both groups, whilst there was a greater intensity of inflammatory response in group PH on both moments. Conclusion: The poli (2-hydroxyethyl methacrylate) polyHEMA hydrogel associated to polypropylene mesh reduces visceral adhesion formation in rats, although it may be associated to greater inflammatory reaction.
\end{abstract}

Key words: Peritoneum. Tissue Adhesions. Hydrogel. Polymers. Surgical Mesh. Polypropylenes. Biocompatible Materials. Rats.

\section{RESUMO}

Objetivo: Verificar se compósito poli 2-hidroxietil dimetacrilato (PoliHEMA) / tela de polipropileno implantado na parede abdominal de ratas seria adequado para prevenção de aderências peritoneais e avaliar a resposta tecidual desencadeada por este biomaterial. Métodos: Foram implantadas telas de polipropileno - Grupo PP $(n=20)$ e telas de polipropileno revestidas por uma camada de poli 2 (hidroxietil dimetacrilato)-PolyHEMA - Grupo PH $(n=20)$ na parede abdominal de ratas da linhagem Wistar. Dez animais de cada grupo foram submetidos à eutanásia aos 15 e 30 dias de pós-operatório. Resultados: Os animais do grupo PP apresentaram aderências viscerais na superfície da tela, o que não foi observado nos do grupo PH. Observou-se no exame histopatológico resposta tipo corpo estranho nos dois grupos sendo que no grupo PH houve maior intensidade de resposta inflamatória nos dois momentos. Conclusão: O hidrogel de poliHEMA quando associado à tela de polipropileno reduz a formação de aderências viscerais em ratos, embora possa estar associado à reação inflamatória mais intensa.

Descritores: Peritônio. Aderências Teciduais. Hidrogel. Polímeros. Telas Cirúrgicas. Polipropilenos. Materiais Biocompatíveis. Ratos.

${ }^{1}$ Research performed at School of Veterinary, Federal University of Goiás (UFG), Goiânia, Brazil.

\section{Introduction}

The issue of incisional hernias and other abdominal wall defects is the recurrence rate after suture primary tissue approximation, therefore demanding the use of meshes for correcting tissue defects. Polypropylene meshes are amongst the most commonly employed biomaterials. It is well tolerated by the organism, it gets integrated to surrounding tissues and offers a great resistance degree to traction on the repair zone ${ }^{1}$. Furthermore, it is a resistant material, of easy manipulation and of low relactive cost, but it easily leads to adhesion formation that may result in postoperative abdominal pain, intestinal obstruction and fistulae formation ${ }^{2,3}$. Under regular conditions, when a mesh is implanted in a organism, there is a foreign body reaction due to the presence and to the threads used in its fixation ${ }^{4,5,6}$ culminating on the formation of na avascular capsule of collagenous fibrous tissue ${ }^{5}$. 
This is the process of mesh incorporation. However, this same process represents the stimulus to definitive adhesion formation and its severe complications, as intestinal obstruction and fistulae formation, mainly if the mesh is placed in intraperitonial position ${ }^{7}$, in direct contact with the visceral surface ${ }^{8}$.

Several methods and agents have been developed to prevent peritoneal adhesion. The most common approach is the creation of physical barriers that impair the contact between the implanted material and intestinal loops or other abdominal or pelvic viscera ${ }^{8,9}$ in order to achieve effective prevention of adhesion when non-absorbable materials with an impervious layer in its ventral surface are implanted on the abdominal wall with direct contact with the intestinal loops ${ }^{9}$. The development of the healing process of the abdominal wall, as well as adhesion formation are related to the size of the mesh pores. Thus, it is known that microporous meshes become progressively encapsulated, with poor infiltration by newly formed tissues. Such materials seldom induce adhesion formation, whilst the macroporous kind and polypropylene are totally infiltrated by a disorganized healing tissue, granting greater resistance to traction at the repair site. Unfortunately, this very characteristic, positive form incorporation perspective induces adhesion formation ${ }^{10}$ that may turn into disappointing outcomes ${ }^{11}$.

In order to minimize or abolish mesh stimulated adhesion formation there is an effort to develop materials, as composites, which present the positive characteristics of both micro- and macroporous meshes. Bellón et al. ${ }^{12}$ stated that it is possible to obtain good results by using combined prosthesis in the form of composite.

The polymers are the most versatile class of biomaterial, thus it has been widely employed on the development of several biomedical devices. Amongst polymers the poly 2-(hydroxyethyl methacrylate) hydrogel (polyHEMA) stands out. It is employed to manufacture contact lenses, skin coatings, immune isolation membranes, and drug liberation system ${ }^{13}$ According to HSIUE et al. ${ }^{14}$, polyHEMA hydrogel presents light weight, it is flexible, biocompatible, non-toxic and has no antigenic properties, factor that altogether stimulate research on its application as medical device. Although polymers are considered effective as biomaterials, special caring must be taking in its use, since its interaction with the tissues and its degradation may bring risks along ${ }^{15}$.

The histological study is vital on the biocompatibility evaluation of a material. The analysis of certain responses from the host, such as inflammatory reaction intensity, fibrosis, cellular pavement foreign body granulomatous inflammation, fibroblastic hyperplasia and quantification of collagen fibers, enable the understanding of organic responses to implants. According to Vural et $a l .{ }^{16}$ the mechanism for intraperitoneal adhesion represents a variation of the regular healing process, thus being the outcome an inflammatory mechanism. The macrophages, the greatest differentiated cells of the phagocytic mononuclear system, respond to biomaterial implantation trying and phagocyting its particles, and its major function is to intermediate immune and inflammatory responses against implanted foreign bodies ${ }^{17}$.

The aim of this study was to assess tissue response and peritoneal adhesion formation after implanting polypropylene mesh coated with a layer of poli (2-hydroxyethyl methacrylate) (polyHEMA) in rats' abdominal wall.

\section{Methods}

This study was approved by the Animal Ethics Committee of Federal University of Goiás (protocol $n^{\circ}$ 054/2008). Forty young Wistar rats were used, weighting from $250 \mathrm{~g}$ and $300 \mathrm{~g}$, allocated in two groups named after the material to be implanted: Group PP (Polypropylene), which was the control group, and group PH (Polypropylene-Hydrogel), which was the experimental group. In each group 10 animals were euthanized 15 and 30 days after the implant.

Polypropylene and polyHEMA hydrogel composites were prepared at the Biomechanics Laboratory of Mechanics Engineering College of State University of Campinas (UNICAMP). The chemical reagents were acquired from Aldrich Chemicals Co., Milwaukee, Wi, USA and the polypropylene mesh was acquired from the brand Intracorp ${ }^{\circledR}$ (Venkuri, São Paulo).

The implant technique was similar for both groups. Anesthetic induction was achieved with intramuscular application of $1 \mathrm{mg} / \mathrm{kg}$ tiletamine/zolazepan (Zoletil ${ }^{\circledR}$, Virbac) and maintained with halothane (Tanohalo ${ }^{\circledR}$, Cristália, São Paulo) in open circuit inhalatory anesthesia device. After a cutaneous incision 1 to $2 \mathrm{~cm}$ left to the median line, a tunnel was created in the subcutaneous space (Figure 1A) and a median laparotomy was carried on, followed by omentectomy and cecum scarification with an interdental sterile brush. A segment of the rectus abdominalis on the right side was removed (Figure 1B) and the defect was corrected by implanting a same sized fragment of the determined biomaterial. Polypropylene thread (Prolene ${ }^{\circledR} 5-0$ ) was employed to fixate the mesh in simple continuous stitches (Figure 1C). Skin was sutured with intradermal stitches with the same thread, caring not to occur overlapping of skin suture onto the implanted material (Figure 1D). Animals were submitted to euthanasia in $\mathrm{CO}_{2}$ chamber at 15 and 30 days after the procedure for macro- and microscopic evaluation of the implanted region.
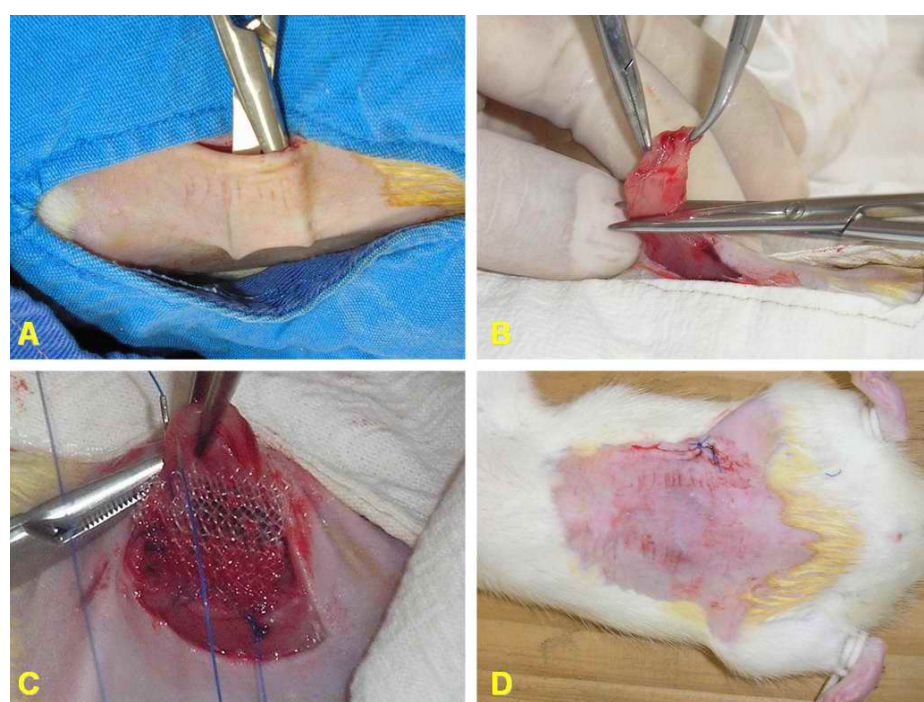

FIGURE 1 - Polypropylene mesh implant for reconstructing defect on rats abdominal wall; (A) Left paramedian cutaneous incision and incision and subcutaneous tunnel creation; (B) Defect creation by removal of right rectus abdominalis segment; (C) Polypropylene mesh sutured with polypropylene thread to correct the defect; (D) Intradermal suture aspect at the end of mesh implant procedure 
The resection of the samples for histological evaluation was done in blocs, including muscle, implanted meshes and adjacent skin. The slices obtained from all fragments were stained with hematoxylin and eosin (HE) e picrosirius. Slides were descriptively and semi quantitatively read, observing the presence of blood vessels, kind of inflammatory infiltration, presence of giant cells and connective type tissue deposited. The psicosirius technique for collagen typification was carried on the 30-day samples of both groups. Two regions were evaluated: Center of the mesh and transition area between the graft and the abdominal wall. Through this technique type I collagen fibers (mature) appear thicker and strongly birefringent, identified by its red-orange coloring. Type III collagen fibers (immature) are thinner, loose and weakly birefringent, identified by its greenish coloring.

Statistical comparison between treatments was carried and, considering that the variables are non parametrical, $U$ Wilcoxon-Mann-Whitney (WMW) test was employed for $\mathrm{p}<0.05$, and descriptive statistical analysis was used to demonstrate the difference between the samples. SAEG and XLSTAT 2008 softwares were employed.

To quantify adhesions, the following score, modified from Greca et al. ${ }^{18}$, was utilized (Chart 1).

CHART 1 - Criteria and scores for peritoneal adhesions classification

\begin{tabular}{|c|c|}
\hline CLASSIFICATION & $\begin{array}{c}\text { NUMERICAL } \\
\text { SCORE }\end{array}$ \\
\hline Lack of adhesion & 1 \\
\hline Omentum adhesion at suture zone & 2 \\
\hline Omentum adhesion to up to 50\% of the material surface & 3 \\
\hline Omentum adhesion to more than 50\% of the material surface & 4 \\
\hline Visceral adhesion at suture zone & 5 \\
\hline Visceral adhesion at material surface & 6 \\
\hline
\end{tabular}

\section{Results}

\section{Macroscopic evaluation}

There was no postoperative death and no sign of infection or rejection to the biomaterial was evident. Fifteen days after meshes implantation, $60 \%$ of group PP animals presented adhesion at the mesh surface, whereas $10 \%$ were omentum adhesion in less than half of the mesh, $20 \%$ in all its surface, and $30 \%$ presented visceral (hepatic or intestinal) adhesion (Figure 2A).

Not an animal from group PH presented mesh surface adhesion, however in $70 \%$ of them there was omentum adhesion at the suture zone (Figure 2B). In 30\% the suture zone adhesion was visceral.

At the 30th day after implantation, $100 \%$ of group PP animals had adhesion on the mesh, and, out of those, $70 \%$ consisted of omentum adhesion in less than half of the mesh, $10 \%$ of omentum in all the mesh surface, and $20 \%$ in viscera. In group $\mathrm{PH}$ there was only adhesions of omentum at the suture zone in $50 \%$ of the animals. One animal developed subcutaneous seroma signs.
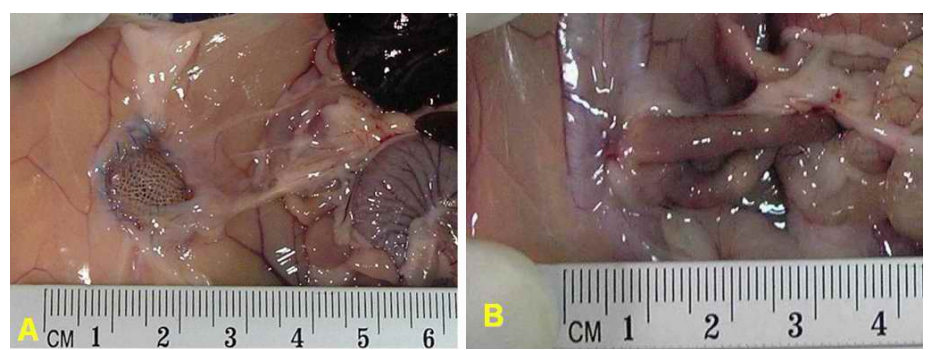

FIGURE 2 - Macroscopic evaluation of abdominal adhesion in rats after polypropylene mesh and polypropylene mesh coated with polyHEMA; (A) Omentum adhesion to the suture zone (Group PH); (B) Intestinal adhesion to the mesh surface (Group PP)

\section{Microscopic analysis}

\section{Group PP - 15 days after implantation}

Moderated angiogenesis was observed in $70 \%$ of the samples, and accentuated in $30 \%$. The predominant infiltrate was mononuclear in $100 \%$, also observing giant cells around polypropylene monofilaments. Loose connective tissue was found in $100 \%$ of the samples, and in $20 \%$ of them some fields containing dense connective tissue were also observed (Figures $3 \mathrm{~A}$ and $3 \mathrm{C}$ ).

\section{Group PH -15 days after implantation}

In this group there was polymorphonuclear inflammatory infiltrated in $50 \%$ of the samples at the surface in contact with the biomaterial. Accentuated mononuclear infiltrated and loose connective tissue were also detected in $100 \%$ of the samples (Figures 3B and 3D). Giant cells were not observed.

There was statistical difference $(p<0.05)$ between the two groups concerning the presence of polymorphonuclear and giant cells.

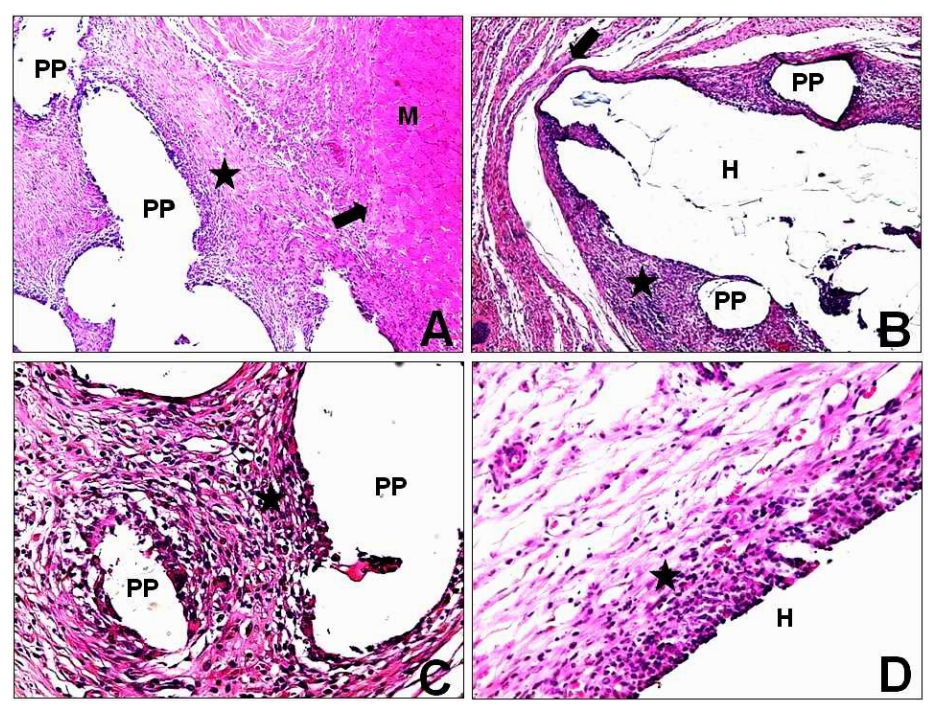

FIGURE 3 - Photomicrography of tissue response to polypropylene mesh implants and polypropylene -hydrogel 15 days after implantation (HE); (A) Evidentiating loose connective tissue around biomaterial, predominance of inflammatory infiltrated (star) and host tissue interface (arrow). Sample from group PP (50x); (B) Sample from group PH (50x); (C) Sample from group PP (200x); (D) Sample from group PH (200x), PP site taken by polypropylene monofilament; $\mathbf{H}$ site taken by hydrogel; M - abdominal wall musculature 


\section{Group PP - 30 days after implantation}

A withdrawal of mononuclear cells intensity was noticed in $80 \%$ of samples. Dense connective tissue concentrically arranged around the monofilaments was found in $80 \%$ of the samples (Figure 4A). Fibroblasts were noticed in $20 \%$ of the samples. Picrosirius staining showed mature collagen (type I) predomination in $80 \%$ of the samples (Figure $5 \mathrm{~A}$ ).

\section{Group PH - 30 days after implantation}

In this group there was a withdrawal of polymorphonuclear count and raise in macrophage. The composite appeared encapsulated mainly by loose connective tissue in $90 \%$ of the samples (Figure 4B). Connective tissue surrounding the entire material could also be evidentiated, and fibroblasts were found between the pores of the material. The collagen formed around the composite was immature (type III) in $90 \%$ of the samples (Figure 5B).

Statistical difference $(p<0.05)$ was observed in angiogenesis, polymorphonuclear and mononuclear presence, besides loose and dense connective tissue.
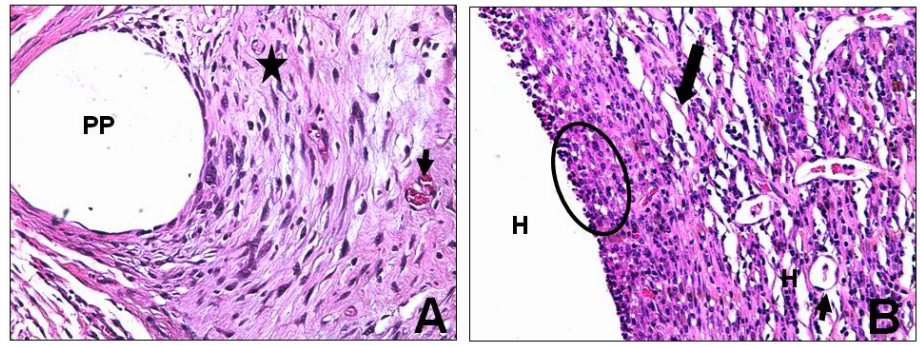

FIGURE 4 - Photomicrography of tissular response to polypropylene mesh and polypropylene-hydrogel implants, 30 days after implantation (HE, 200x); (A) Group PP sample evidentiating dense connective tissue around the polypropylene monofilament biomaterial (arrow) and angiogenesis (short arrow); (B) Sample from group PH with presence of loose connective tissue (long arrow), accentuated mononuclear presence (circle) and angiogenesis. Whereas: PP - site taken by polypropylene monofilament; $\mathbf{H}$ - site taken by hydrogel
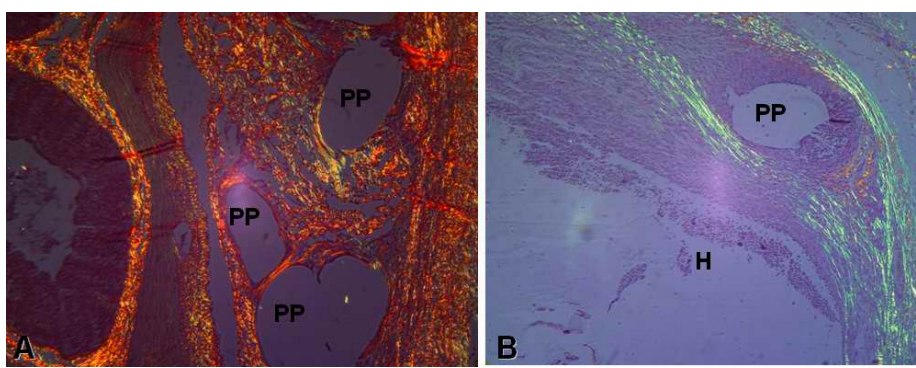

FIGURE 5 - Photomicrographies in polarized light of a group PP sample (A) and of group PH (B), 30 days after the implantation (picrosrius, 100x). Evidencing the predominance of type I colagen (mature) with red coloration and type III colagen (imature), with green coloration. Whereas: PP Site taken by polypropylene monofilament; $\mathbf{H}$ Site taken by hydrogel

\section{Discussion}

Although widely employed on abdominal wall defects repairing due to its low cost and excellent incorporation characteristics, polypropylene mesh is associated to high occurrence of peritoneal adhesion. In order to eliminate this complication, efforts have been made towards the development of materials with a non-adherent surface. PolyHEMA hydrogel has been employed on the confection of several biomedical devices ${ }^{13,14}$, but there are no reports in literature of its use in intraperitoneal space, which brings up the interest in the evaluation of polypropylene as coating material to prevent adhesion formation.

In this essay it was possible to notice good tolerance to the composite used, characterized by the lack of rejection to it even after implantation. The presence of subcutaneous seroma in one animal from group PH may be related to the creation of the subcutaneous tunnel necessary to avoid the overlapping of the cutaneous wound onto the suture zone.

Concerning adhesion presence, these have presented to be tight on the central area of the prosthesis on group PP animals, in opposition to what was noticed on group PH in which they were loose and situated at the suture zone, what may be justified by the presence of greater inflammation on this transition region due to the suture material presence, since it also acts as a foreign body which may incite adhesion formation ${ }^{4}$.

The polyHEMA hydrogel which coated the polypropylene mesh did not allow the adhesion of fibrin bundles onto itself due to its linear and microporous configuration. As for the adhesions of omentum remaining on the edges of the mesh have no clinical significance in human beings, since the omentum is, for itself, usually employed as a barrier to prevent visceral adhesion when meshes are implanted, contrary to what happens when adhesions are visceral ${ }^{1}$. Such fact justifies our choice to proceed omentectomy in animals.

Histological data showed that meshes in both groups led to a persistent inflammatory reaction onto the biomaterial interface and host tissue. Although polymers are used on the confection of several biomedical devices, its application on live tissues must be careful, mainly when it comes to laboratory maid material. According to Suh ${ }^{15}$ the interaction of polymers and tissues as well as the products of its degradation when in contact with organic liquids may determine unpredictable responses. The evolving of the repairing process is conditioned to the structure of the biomaterial employed, since it is made of chemical agents. In all of the cases there is the development of a foreign body inflammatory response, characterized by the presence of macrophage connective tissue and giant cells ${ }^{6}$. In this essay, group PH presented acute, although moderated, inflammation on the $15^{\text {th }}$ day after implantation, which may be attributed to a possible liberation of residual monomers present on the biomaterial.

The polymorphonuclear infiltrate found may be involved in the pathophysiology of adhesion formation on the $\mathrm{PH}$ coated mesh periphery, which was more frequent at 15 days. In such context Bellón et al. ${ }^{1}$ stated that the peritoneal lesion, during surgery, in lack of infection, leads to a fast influx of neutrophils which may result in adhesion formation. Thus, alteration on phagcytosis mechanism may be very important to adhesion formation ${ }^{17}$.

The presence of macrophages on animals from group $\mathrm{PH}$ was outlined on both periods of observation. Whilst on group PP the intensity was overdrawn from accentuated to moderate at 30 days. When biomaterial are implanted in an organism, different reaction patterns may be expected, however, it is known that liberated cytokines and growth factors Will act upon the recruiting mainly of neutrophils. Other cells, such as the monocytes, Will 
differentiate into macrophages, whose finality is to remove the material. But if the foreign body is significantly bigger than the macrophages there will be no phagocytosis and these defense cells, in the form of giant cells, will endure around the material throughout $\operatorname{life}^{6}$. In this essay, the accentuated quantity of macrophages seen in group PH may have been occasioned by the volume of implanted material, as well as by its chemical characteristic. It is known that macrophage response also depends on the biomaterial size ${ }^{18}$ and in this essay a material incapable to be phagocyted was employed.

The choice of non-degradable materials must be conditioned to its ability to cause minimal macrophage response on the implants on the long run. On this essayimmature collagen (type III) was observed in group PH samples, although macroscopically the wounds were healed. Once more, the probable presence of residual monomers may have contributed for this finding, even though Xia et al. ${ }^{17}$ outline that macrophage in its phagocytosis of debris produce an spectrum that include proteinasis, colagenasis, elastasis and hyaluronidases.

Polypropylene mesh associated to hydrogel was completely surrounded by connective tissue, in contrast to non-coated polypropylene, in which this tissue predominated around the polypropylene mesh. According to Bellón et al. ${ }^{1}$, the contrasting connective deposit pattern is due to the differences in texture and porosity of each biomaterial. These authors also reported that macroporous biomaterial, such as polypropylene, becomes totally infiltrated by a non-organized mass of fibrous tissue, granting it great traction resistance at the repair zone.

\section{Conclusion}

The poli 2 (hidroxietil dimetacrilato) PolyHEMA hydrogel, when associated to polypropylene mesh reduces formation of visceral adhesion in rats, although it may be related to inflammatory reaction of greater intensity that the one triggered by non-coated polypropylene mesh.

\section{References}

1. Bellón JM, Contreras LA, Bujan J, Palomares D, Carrera-San A. Tissue response to polypropylene meshes used in the repair of abdominal wall defects. Biomaterials. 1998; 19:669-75.

2. Dinsmore RC, Calton WC, Harvey SB, Blaney MW. Prevention of adhesions to polypropylene mesh in a traumatized bowel model. J Am Coll Surg. 2000;191:131-6.
3. Felemovicius I, Bonsack ME, Hagerman G, Delaney JP. Prevention of adhesions to polypropylene mesh. J Am Coll Surg. 2004;198:543-8.

4. Borrazo EC, Belmont MF, Bolfa D, Fowler DL. Effect of prosthetic material on adhesion formation after laparoscopic ventral hérnia repair in a porcine model. Hernia. 2004;8:108-12.

5. Matthews BD, Pratt BL, Pollinger HS, Backus CL, Kercher KW, Sing RF, Heniford BT. Assessment of adhesion formation to intra-abdominal polypropylene mesh and polytetrafluoroethylene mesh. J Surg Res. 2003;114:126-32.

6. Ratner BD, Bryant SJ. Biomaterials: Where we have been and where we are going. Ann Rev Biomed Eng. 2004;6:41-75.

7. van t 'Riet M, van Steenwijk PJ de V, Bonthuis F, Marquet RL. Prevention of adhesions to prosthetic mesh: comparison of different barriers using an incisional hernia model. Ann Surg. 2003;237:123-8.

8. Sahin M, Cakir M, Avsar, FM, Tekin A, Kucukkartallar T, Akoz M. The effect of anti-adhesion materials in preventing postoperative adhesion in abdominal cavity (anti-adhesion materials for postoperative adhesions). Inflammation. 2007;30(6):244-9.

9. Losanof JE, Richman BW, Jones JW. Entero-cutaneous fistula: a late consequences of polypropylene mesh abdominal wall repair: case report and review of the literature. Hernia. 2002;6:144-7.

10. Klinger U, Klosterhalfen B, Müller M, Schumpelick V. Foreign body reaction to meshes used for the repair of abdominal wall hernias. Eur J Surg. 1999;165:665-73.

11. Burger JWA, Halm JA, Wijsmuller AR, ten Raa S, Jeckel J. Evaluation of new prosthetic mesh for ventral hernia repair. Surg Endosc. 2006;20:1320-5

12. Bellón JM, Carranza-García A, Jurado F, Garcia-Honduvilla N, Carrera-San Martin A, Buján J. Peritoneal regeneration alter implant of a composite prótesis in the abdominal wall. World J Surg. 2001;25:147-52.

13. Angelova N, Hunkeler D. Rationalizing the design of polymeric biomaterials. Trends Biotechnol. 1999;17:409-21.

14. Hsiue GH, Guu JA, Cheng CC. Poly(2-hydroxyethyl methacrylate) film as a drug delivery system for pilocarpine. Biomaterials. 2001;22:1763-9. 15. Suh $\mathrm{H}$. Tissue restauration, tissue engineering and regenerative medicine. Yonsei Med J. 2000;41:681-4.

16. Vural B, Cantürk NZ, Esen N, Solacoglu S, Cantürk Z, Kirkali G, Sökmensüer C. The role of neutrophils in the formation of peritoneal adhesions. Hum Reprod. 1999;14:49-54.

17. Xia Z, Triffitt J. A review on macrophage responses to biomaterials. Biomed Mater. 2006;1(1):R1-9.

18. Greca FH, Paula JB, Biondo-Simões MLP, Costa FD, Silva APG, Time S, Mansur A. The influence of differing pore sizes on the biocompatibility of two polypropylene meshes in the repair of abdominal defects. Hernia. 2001;5:59-64.

\section{Correspondence:}

Conflict of interest: none Neusa Margarida Paulo

Universidade Federal de Goiás, Escola de Veterinária

Departamento de Medicina Veterinária

74001-970 Goiânia - GO Brazil

nmp@,vet.ufg.br

Financial source: CNPQ

Received: January 11, 2010

Review: March 15, 2010

Accepted: April 19, 2010

\section{How to cite this article}

Paulo NM, Malmonge SM, Menezes LB, Lima FG, Faria AM, Andrasckho MM, Moreira M, Moreira NM, Atayde IB, Brito e Silva MS. Evaluation of peritoneal adhesions formation and tissue response to polypropylene - poli (2-hydroxyethyl methacrylate)-(polyHEMA) implant on rats' abdominal wall. Acta Cir Bras. [serial on the Internet] 2010 July-Aug;25(4). Available from URL: http://www.scielo.br/acb 